\title{
ORC1 Gene
}

National Cancer Institute

\section{Source}

National Cancer Institute. ORC1 Gene. NCI Thesaurus. Code C20386.

This gene plays a role in DNA binding, initiation of DNA replication and transcriptional silencing. It is also involved in AT P hydrolysis and the maintenance of cell viability. 